\title{
„Revista de Derecho Agrario y Alimentario"
}

Carlos Coello Martín, Fernando González Botija, Reciente jurisprudencia sobre comercialización de vinos - declaraciones saludables y uso de la misma marca comercial para identificar vinos procedentes de distintas denominaciones de origen (Najnowsze orzecznictwo dotyczące wprowadzania do obrotu win - oświadczenia zdrowotne i kwestia korzystania z tego samego znaku towarowego celem zidentyfikowania win korzystających z różnych chronionych nazw pochodzenia), RDAA 2013, nr 62, s. 33-57.

Problematyka związana z wprowadzaniem do obrotu produktów winiarskich stała się przedmiotem rozważań Europejskiego Trybunału Sprawiedliwości już w latach osiemdziesiątych XX w. W jednym z najnowszych orzeczeń TSUE wyraził pogląd, iż art. 4 ust. 3 par. 1 rozporządzenia (WE) nr 1924/2006 Parlamentu Europejskiego i Rady z 20 grudnia 2006 r. w sprawie oświadczeń żywieniowych i zdrowotnych dotyczących żywności (pojęcie oświadczenia zdrowotnego) należy interpretować w rozumieniu pojęcia „oświadczenia o właściwościach zdrowotnych”, które zawiera w sobie opis ,lekkostrawny” i towarzyszy mu wzmianka o obniżonej zawartości substancji często postrzeganych przez konsumentów jako szkodliwe.

Zdaniem hiszpańskiego Sądu Najwyższego jest możliwe, że znak towarowy może określać wina z różnych regionów i stref uprawy win zawsze wtedy, gdy chroniona nazwa pochodzenia to umożliwia. Jednakże jedynie w sytuacji, gdy znak towarowy w sposób w sposób jasny i prosty określa identyfikację chronionej nazwy pochodzenia, w sposób niewprowadzający w błąd bądź niepowodujący niejasności interpretacyjnych. 
Andrés Miguel Cosialls Ubach, José María de la Cuesta Sáenz, Esther Muñiz Espada, Perspectivas legislativas agrarias para Castilla y León: apuntes a propósito de la presentación de su nuevo anteproyecto legislativo (Perspektywy prawnorolne dla Wspólnoty Autonomicznej Castilla y León: rozważania w nawiązaniu do prezentacji nowego projektu wstępnego legislacji regulującej niniejsze aspekty), RDDA 2013, nr 62, s. 59-92.

Autorzy uważają, że przyszłe ustawodawstwo dotyczące prawnych aspektów rolnictwa we Wspólnocie Autonomicznej Castilla y León winno bazować na fundamentach hiszpańskiego oraz europejskiego systemu prawnego, a także na uniwersalnych wartościach, a więc przede wszystkim na Konstytucji Hiszpanii, tradycjach rolnych i wiejskich Wspólnoty Castilla y León, na Wspólnej Polityce Rolnej oraz na pozostałym ustawodawstwie Unii Europejskiej, a także na porozumieniach zawartych w ramach działalności Światowej Organizacji Handlu (WTO).

Uwzględnienie powyższego doprowadzić ma do znacznego uproszczenia procedur administracyjnych, a co za tym idzie - zapobieżenia nadmiernej biurokratyzacji, a także przyczynić się ma do rozwoju obszarów wiejskich; kwestii kluczowej z perspektywy dalszego rozwoju Wspólnoty. Podstawowe założenia projektu stanowią o przeznaczeniu większej powierzchni Wspólnoty Autonomicznej pod produkcję rolną, modernizacje gospodarstw rolnych (w tym pomoc młodej generacji rolników w ich prowadzeniu na własny rachunek) oraz wsparcie producentów rolnych przy wprowadzaniu produktów rolno-spożywczych na rynek Hiszpanii i Unii Europejskiej. Planowana reforma ma przyczynić się do zwiększenia samowystarczalności gospodarstw rolnych, które mają stać się konkurencyjne wobec innych producentów rolnych z terenów Unii Europejskiej.

Angel Sánchez Hernández, La Ley 43/2003, de 21 de noviembre, de montes: reflexiones desde el Derecho civil (Ustawa nr 43/2003 z 21 listopada 2003 r. o gruntach leśnych: refleksje z punktu widzenia prawa cywilnego), RDAA 2013, nr 62, s. 93-136.

Z punktu widzenia rozwoju obszarów wiejskich grunty leśne w Hiszpanii zyskały strategiczne znaczenie. Dlatego $\mathrm{w}$ hiszpańskim systemie prawnym wprowadzono liczne obowiązki, które muszą spełnić właściciele gruntów leśnych tak, aby chronić generalny, publiczny i prywatny interes państwa. Ustawa o gruntach leśnych systematyzuje oraz uporządkowuje wcześniej obowiązującą regulację. Ma ona uwzględniać społeczny wymiar gruntów leśnych, jak również ochronę środowiska oraz biologicznego charakteru gruntów leśnych.

Nowa legislacja opiera się na koncepcji samowystarczalności lasów, a więc ich wielofunkcyjności, zawarciu planowania zagospodarowania przestrzennego gruntów leśnych w krajowym planie zagospodarowania przestrzennego, wprowadzeniu spoistości terytorialnej oraz subsydiarności, większego niż do tej pory zalesienia obszarów wiejskich oraz wprowadzenia do obrotu większej ilości produktów pochodzących 
z gruntów leśnych, zachowanie leśnej bioróżnorodności oraz ustanowienie współpracy pomiędzy udziałowcami a przedstawicielami władzy poszczególnych wspólnot autonomicznych czy też państwowej. Jednym z głównych założeń nowej legislacji było ograniczenie swobody dysponowania gruntami leśnymi przez ich właścicieli i ten cel udało się w pełni osiagnąć. W świetle nowej regulacji prawna własność gruntów leśnych została ściśle ograniczona przez społeczną funkcję własności, tym samym określiła prawa i obowiązki właścicieli gruntów leśnych.

Héctor Simón Moreno, Las utilidades del "Trust" en el ámbito agrario (Użyteczność zarządzeń powierniczych w środowisku rolnym), RDAA 2013, nr 62, s. 137-172.

Ustawa nr 19/1995 z lipca 1995 r. o modernizacji gospodarstw rolnych została wprowadzana w celu rozwiązania niedoborów strukturalnych, które w sposób istotny ograniczały ich konkurencyjność. Szczególnie dotyczyło to problemów związanych z niewielkim rozmiarem gospodarstw rolnych, starzeniem się społeczeństwa pracującego przy produkcji rolnej, brakiem elastyczności produkcji rolnej oraz niewydolnym zarządzeniem gospodarstwem rolnym jako przedsiębiorstwem.

Poprzednie ustawodawstwo nie spełniło żadnego ze wspomnianych założeń, dlatego konieczne okazało się wprowadzenie zmian. Zdaniem autora hiszpańskie gospodarstwa rolne cechuje brak innowacyjności i konkurencyjności wobec silnej konkurencji innych państw Unii Europejskiej. Niezbędny asumpt do dalszego rozwoju stanowi skorzystanie z wywodzącej się z prawa anglo-amerykańskiego instytucji zarządzeń powierniczych. Skorzystanie z tej alternatywnej formy rozwoju gospodarstw rolnych ma przyczynić się do osiagnięcia wydajnego, profesjonalnego oraz konkurencyjnego zarządzania gospodarstwem rolnym - celu wyraźnie wspieranego przez Unię Europejską w Wspólnej Polityce Rolnej na lata 2014-2020.

Opracowanie: KRZYSZTOF RÓŻAŃSKI 